\title{
SUSPENDED ELECTRODIALYTIC EXTRACTION OF TOXIC ELEMENTS FOR DETOXIFICATION OF THREE DIFFERENT MINE TAILINGS
}

\author{
P.E. JENSEN ${ }^{1}$, L.M. OTTOSEN ${ }^{1}$, H.K. HANSEN ${ }^{2}$, S. BOLLWERK ${ }^{1}$, L.J. BELMONTE ${ }^{1} \&$ \\ G.M. KIRKELUND ${ }^{1}$ \\ ${ }^{1}$ Department of Civil Engineering, Technical University of Denmark, Denmark \\ ${ }^{2}$ Departamento de Ingeniería Química y Ambiental, Universidad Técnica Federico Santa Maria, \\ Valparaíso, Chile
}

\begin{abstract}
Environmental effects of mining activities partly origin from the production of tailings, and the exposure of these to ambient physical and chemical conditions. Removal of toxic elements from tailings prior to deposition could improve environmental performance and reduce risks. Experimental results have shown that electrokinetic treatment can remove $\mathrm{Cd}, \mathrm{Cu}, \mathrm{Pb}$, and $\mathrm{Zn}$ from tailings soils; As from tailings; and $\mathrm{Cu}$ from tailings. Still, however, a major concern is the long treatment-time required for the element-transport through the tailings matrix. Therefore several enhancement methods have been investigated including pre-treatment of the tailings with acid; insertion of bipolar electrodes; and implementation of pulsed or sinusoidal electric fields. In line with these efforts, we investigated the efficiency when extracting toxic elements from a suspension of tailings, rather than from a solid matrix, which could well be implemented as a final treatment step prior to deposition of tailings. Six electrodialytic experiments in laboratory scale with three different mine tailings (Codelco, Zinkgruvan, and Nalunaq) show that it is possible to extract residual $\mathrm{Cu}$ from the all the three suspended mine tailings, although with some difference between the tailings. From the Zinkgruvan sediment, which had the lowest $\mathrm{Cu}$ removal, $\mathrm{Pb}$ could also be extracted, while $\mathrm{Cd}$ and $\mathrm{Zn}$ were less extractable.
\end{abstract}

Keywords: decontamination, detoxification, electrodialysis, heavy metals, mine tailings, remediation, resource recovery.

\section{INTRODUCTION}

A major environmental effect of mining activities origin from the deposition of tailings and the exposure of these to ambient physical and chemical conditions. In modern mining, special precautions must be made. In this regard, special attentions should be paid to tailing handling and tailing deposition. One method in development for detoxification of tailings is electrokinetic (EK) or electrodialytic (ED) extraction of left toxic elements.

Experimental results have shown that the application of a direct current field (EK) over tailings can be used to remove $\mathrm{Cd}, \mathrm{Cu}, \mathrm{Pb}$, and $\mathrm{Zn}$ from tailings soils [1, 2]; As from tailings $[3,4]$; and $\mathrm{Cu}$ from tailings [5-7]. Still, however, a major concern is the long treatment-time required for element-transport through the tailings matrix. Therefore, several enhancement methods have been investigated to decrease treatment time: Improvements were obtained for removal of $\mathrm{Cu}$ from $\mathrm{Cu}$ mine tailings by: pre-treatment of tailings with acid (sulphuric or citric acid) [8,9]; insertion of bipolar electrodes to accumulate $\mathrm{Cu}$ [10]; and implementation of pulsed electric fields [5] or sinusoidal field [11,12]. It was also shown that the energy 
consumption for treatment of arsenic tailings (but not treatment time) could be reduced by the combination of EK treatment and anaerobic bioleaching [13].

When comparing treatment of fresh $(<2$ years old) and aged ( $>20$ years old) tailings, it was observed that although removal of $\mathrm{Cu}$ from fresh tailings improved significantly by pretreatment with acid, removal from aged tailings was shown even more efficient - without acid pre-treatment. This is due to the natural acidification occurring by oxidation of sulfide minerals during the aging process [6,9]. It was shown for other materials such as ashes and sludge that ED treatment time can be significantly reduced by treatment in a homogenously stirred suspension, as opposed to a solid matrix [14]. The main effect is thought to be the reduced transport distance between the material to be treated, and the electrode compartments. However energy and time may also be saved by the avoided build-up of polarization phenomena, which are also the phenomena approached when applying pulsed current and sinusoidal current fields $[5,11,12]$. It was shown that $\mathrm{Cu}$ can be removed from fresh tailings by ED treatment in suspension, when suspended in sulphuric acid, and that the rate of removal increases with degree of suspension [15]. However, later results showed that even when suspending in water, the extraction proceeded well, and did not differ between aged and fresh tailings; indicating occurrence of enhanced oxidation during treatment in suspension [7].

The aim of this work is to further evaluate the potential of treating mine tailings by electrodialysis in suspension through comparison of extraction of $\mathrm{Cu}$ from three tailings of different origin, - climatic, geological as well as process wise; and by comparison of extraction of different elements $(\mathrm{Cd}, \mathrm{Cu}, \mathrm{Ni}, \mathrm{Pb}, \mathrm{Zn})$ from one of the tailings.

\section{MATERIALS AND METHODS}

\subsection{Materials}

The mine tailings used were:

a. From the Codelco-El Teniente $\mathrm{Cu}$ mine in VI Region in Chile. The orebody at El Teniente mine comprises mainly the El Teniente Mafic Complex (CMET, Andesite), Dacite Porphyry, Tonalite, Diorite Porphyry and the Breccia Braden Complex [16]. The ore, which consists of porphyry copper sulfides, was crushed, milled and concentrated by flotation onsite at 2,300 $\mathrm{m}$ altitude in the Andes Mountains. The tailings mainly contain quartz, muscovite ferric clinochlore, calcic albite, anorthite and hydrated calcium sulphate with copper present as chalcocite, brochantite, chalcopyrite, ramsbeckite, wroewolfeite, and guildite [17]. Apart from copper, the tailings contain lead, cadmium and zinc and arsenic. The mine tailings where sampled directly from the canal which transports the tailings from the copper sulfide concentration plant to the Caren tailing dam (around $1,000 \mathrm{~m}$ above sea level) $87 \mathrm{~km}$ downhill. Around 40,000,000 tonnes tailings are deposited in the dam each year.

b. From the zink, copper and lead mine Zinkgruvan in southern Sweden. The Zinkgruvan deposit belongs to the Proterozoic aged Bergslagen greenstone belt, and hosts massive Zn, $\mathrm{Pb}, \mathrm{Cu}$, and $\mathrm{Ag}$ sulfides and banded iron-formations in volcano-sedimentary complexes [18]. The mineral processing of the ore takes place on-site and consists of autogenous grinding in combination with bulk/selective flotation [19]. The tailings mainly contain quartz, feldspar and calcite and are characterized by substantial concentration of carbonate minerals, whereas just small quantities of sulfides are present [20]. The tailings are considered as non-producing acid rock drainage (ARD) with a low weathering rate [19]. The production of the tailings was around 850,000 tonnes per year. The material used for the experiment consists of the fine fraction of the tailings, which had been transferred to a tailings pond near the site. At the time of sampling, the tailings were younger than 2 years, 
but had been exposed to weathering and atmospheric oxidation.

c. From the gold mine Nalunaq in southern part of Greenland. The deposit is classified as a mesothermal vein-type gold deposit hosted in metavolcanic rocks [21] and the surrounding region is characterized as a gold province with several promising occurrences $[22,23]$. The ore, which consists of a gold-bearing quartz vein (known as the main vein) and proximal hydrothermally altered dolerites and amphibolites [24], was crushed, milled, and treated by cyanide leaching in an extraction plant on-site. The tailings slurry was subjected to detoxification using the Inco method [25] and subsequently pumped into a tailings dam located in previously exploited levels of the mine. At the time of sampling, the estimated tailing production was 50,000-70,000 tonnes per year. In this study, tailings were obtained from the discharge of the detoxification tank before going into the tailings dam. The sampled slurry contained $20 \%-22 \%$ solids, which were left to settle before the excess water was decanted.

\subsection{Electrodialysis experiments}

Electrodialysis experiments were made in cylindrical Plexiglas-cells with three compartments. Compartment II, which contained the tailings-slurry, was $5 \mathrm{~cm}$ long and $8 \mathrm{~cm}$ in inner diameter. The setup is visualized in Fig. 1a and b.

The slurry was kept in suspension by constant stirring with plastic-flaps attached to a glassstick and connected to an overhead stirrer. The anolyte was separated from the soil specimen by an anion-exchange membrane, and the catholyte was separated from the soil specimen by a cation-exchange membrane (AR204SZRA and CR67 HVY HMR427 from Ionics), respectively. Platinum coated titanium electrodes were used as working electrodes. The catholyte and the anolyte initially consisted of $0.01 \mathrm{M} \mathrm{NaNO}_{3}$ adjusted to $\mathrm{pH} 2$ with $\mathrm{HNO}_{3}$. $\mathrm{pH}$ in the catholyte was kept between 1 and 2 by manual addition of $\mathrm{HNO}_{3}(7 \mathrm{M})$. The liquid to solid ratio (L/S) was 4 (25 g air-dried tailings and $100 \mathrm{~mL}$ distilled water). All experiments lasted for 1 week. An overview of the experimental variables (material, suspension liquid, and current density) is given in Table 1.

After the closure of the experiments, electrodes were rinsed in $5 \mathrm{M} \mathrm{HNO}_{3}$, and membranes in $1 \mathrm{M} \mathrm{HNO}_{3}$. Samples of all liquids including electrolytes were saved for analysis. The tailings suspension was filtered through filter paper, and a sample of the filtrate saved for analysis. The wet tailings were dried at $105^{\circ} \mathrm{C}$ overnight and saved for the analysis of $\mathrm{Cd}, \mathrm{Cu}$, $\mathrm{Ni}, \mathrm{Pb}$, and $\mathrm{Zn}$. Analysis of the elements in the tailings and process liquids was made prior to and after the experimental treatment. Non-acidic liquid samples were preserved with one part of concentrated $\mathrm{HNO}_{3}$ to four parts of liquid prior to analysis.
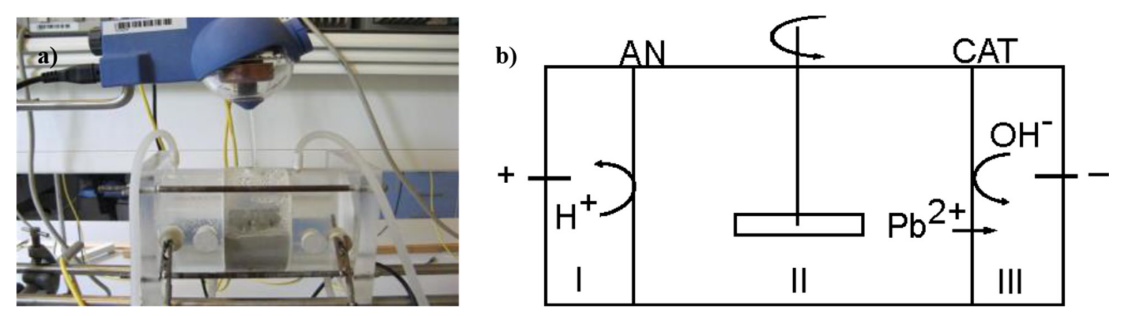

Figure 1 (a) Picture of the experimental setup (b) Schematic view of a cell used for experimental ED treatment of tailings in suspension: anion-exchange membrane (AN), cation-exchange membrane (CAT), anolyte compartment (I), compartment containing sediment slurry (II), catholyte compartment (III). 
Table 1: Electrodialytic experiments.

\begin{tabular}{lc}
\hline Experiment & Current $\left(\mathrm{mA} / \mathrm{cm}^{2}\right)$ \\
\hline Codelco1 & 0.1 \\
Codelco2 & 0.2 \\
Zinkgruvan1 & 0.1 \\
Zinkgruvan2 & 0.2 \\
Nalunaq1 & 0.1 \\
Nalunaq2 & 0.2 \\
\hline
\end{tabular}

2.3 Analytical methods

As, $\mathrm{Cd}, \mathrm{Cu}, \mathrm{Ni}, \mathrm{Pb}$, and $\mathrm{Zn}$ were analyzed by ICP-OES (Varian 720-ES, Software version: 1.1.0) or for $\mathrm{Cu}$ and $\mathrm{Zn}$ by AAS (for the Codelco sediment) after digestion according to the Danish standard method DS259 [26] which includes acid digestion of $1 \mathrm{~g}$ dry tailings material with $20.00 \mathrm{~mL}$ of $7 \mathrm{M} \mathrm{HNO}_{3}$ in autoclave at $200 \mathrm{kPa}$ and $120^{\circ} \mathrm{C}$ for 30 minutes. The element-content in solution was measured by ICP-OES after filtration through a $0.45 \mu \mathrm{m}$ filter. $\mathrm{pH}$ was measured by a Radiometer electrode. All analyses were made in triplicate.

\section{RESULTS AND DISCUSSION}

\subsection{Initial content and mass balances}

The content of the analyzed elements in the tailings prior to treatment is shown in Table 1 . All tailings had higher copper content than average earth's crust [27]. Both Zinkgruvan and Nalunaq had more cadmium and lead than average earth's crust, although Zinkgruvan much more pronounced than Nalunaq. In addition, Zinkgruvan had a high zinc content compared to average earth's crust content, and Nalunaq a high arsenic content. The nickel content is not elevated in any of the two samples for which it was analyzed.

The mass balances for all element for which remediation results are reported, understood as the mass found in the ED-cell system after experimental treatment in percent of the mass calculated from the initial analysis of the untreated tailings were all between $70 \%$ and $101 \%$. The deviations can be explained by the inhomogeneity of the material illustrated by the significant standard deviations in the initial content of the analyzed elements (Table 2). Upon on this observation, the percentage distribution in the compartments of the cell was calculated based on the total final amount found.

\subsection{Experimental performance}

The $\mathrm{pH}$ decreased during treatment from natural to just below 2.5 (Figure 2) due to the acid produced in the ED-cell by water-splitting at the anion-exchange membrane described by [28].

\subsection{Element extraction}

The final concentration of the investigated elements can be seen in Table 3, and the final distribution of $\mathrm{Cu}$ in the ED cell can be seen in Fig. 3. Figure 4 shows the final distribution of 
Table 2: Initial content of selected elements in the tailings ( $\mathrm{mg} / \mathrm{kg} \pm \mathrm{stdev})$.

\begin{tabular}{lcccccc}
\hline & $\mathrm{As}$ & $\mathrm{Cd}$ & $\mathrm{Cu}$ & $\mathrm{Ni}$ & $\mathrm{Pb}$ & $\mathrm{Zn}$ \\
\hline Codelco & na & na & $997 \pm 19$ & na & na & $62 \pm 3.5$ \\
Zinkgruvan & $21 \pm 2$ & $11 \pm 0.2$ & $372 \pm 28$ & $24 \pm 3$ & $3,700 \pm 233$ & $7,331 \pm 322$ \\
Nalunaq & $122 \pm 35$ & $2.8 \pm 0.9$ & $105 \pm 28$ & $48 \pm 13$ & $59 \pm 14$ & $45 \pm 22$ \\
\hline
\end{tabular}
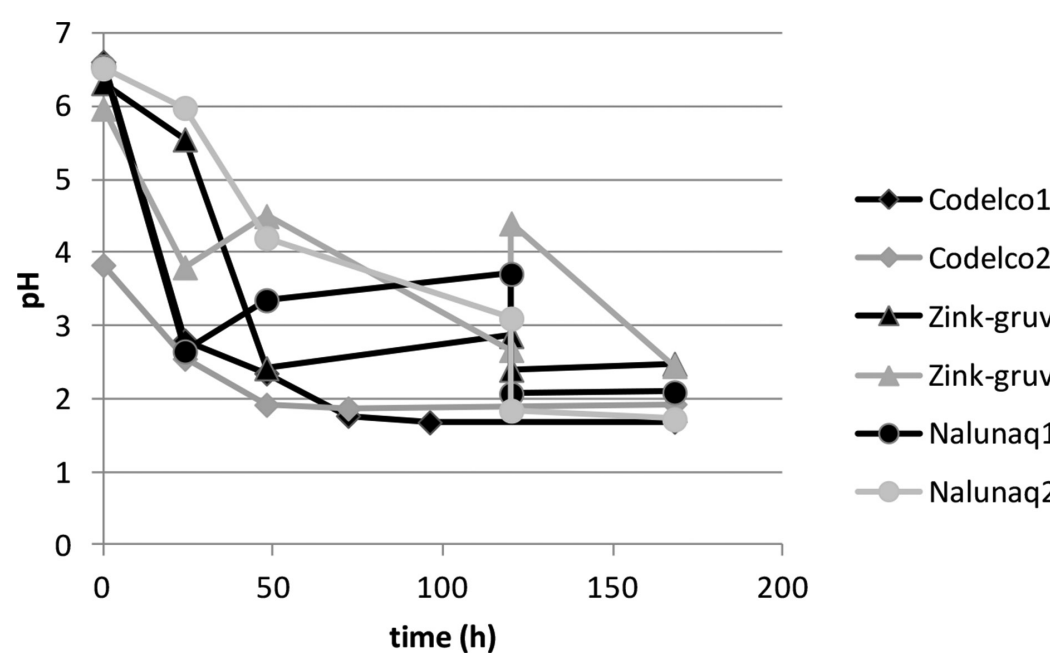

$\neg$ Codelco 2

$\rightarrow$-Zink-gruvan1

- Zink-gruvan2

-•-Nalunaq1

Nalunaq2

Figure 2: $\mathrm{pH}$ development of tailings slurry during ED treatment.

Table 3: Elements after one week of ED treatment $(\mathrm{mg} / \mathrm{kg})$.

\begin{tabular}{lcccc}
\hline & $\mathrm{Cd}$ & $\mathrm{Cu}$ & $\mathrm{Pb}$ & $\mathrm{Zn}$ \\
\hline Codelco1 & na & 475 & na & na \\
Codelco2 & na & 420 & na & na \\
Zinkgruvan1 & 8.9 & 244 & 1,436 & 4,543 \\
Zinkgruvan2 & 8.0 & 221 & 1,323 & 4,090 \\
Nalunaq1 & na & 70 & na & na \\
Nalunaq2 & na & 43 & na & na \\
\hline
\end{tabular}

$\mathrm{Cd}, \mathrm{Pb}$, and $\mathrm{Zn}$ in the Zinkgruvan tailings. The $\mathrm{Cu}$ concentration was reduced in all experiments (Table 3), indicating that extraction of copper by ED extraction from tailings may be obtained on a general basis and not only for the specific tailings type of Codelco, which was investigated previously $[7,15]$.

The copper removal was however more efficient from the Codelco tailings, and least efficient from the Zinkgruvan tailings at identical experimental conditions, both when comparing amount of copper removed and when comparing percentage of copper removed (Fig. 3). The removal was slightly more efficient at the higher current density compared to the lower current density for all three tailings. 


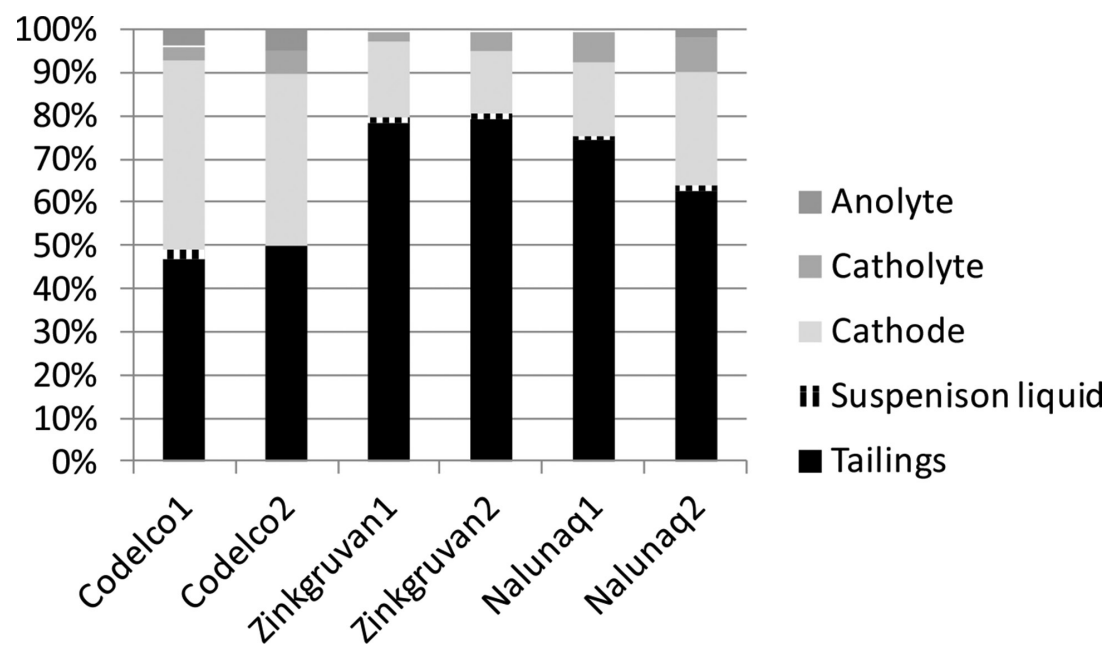

Figure 3: Results of the six electrodialysis experiments expressed as percent of the $\mathrm{Cu}$ found in the various compartments of the ED cell. The amount in the electrolytes include small amounts $(<1 \%)$ found in the membrane material.

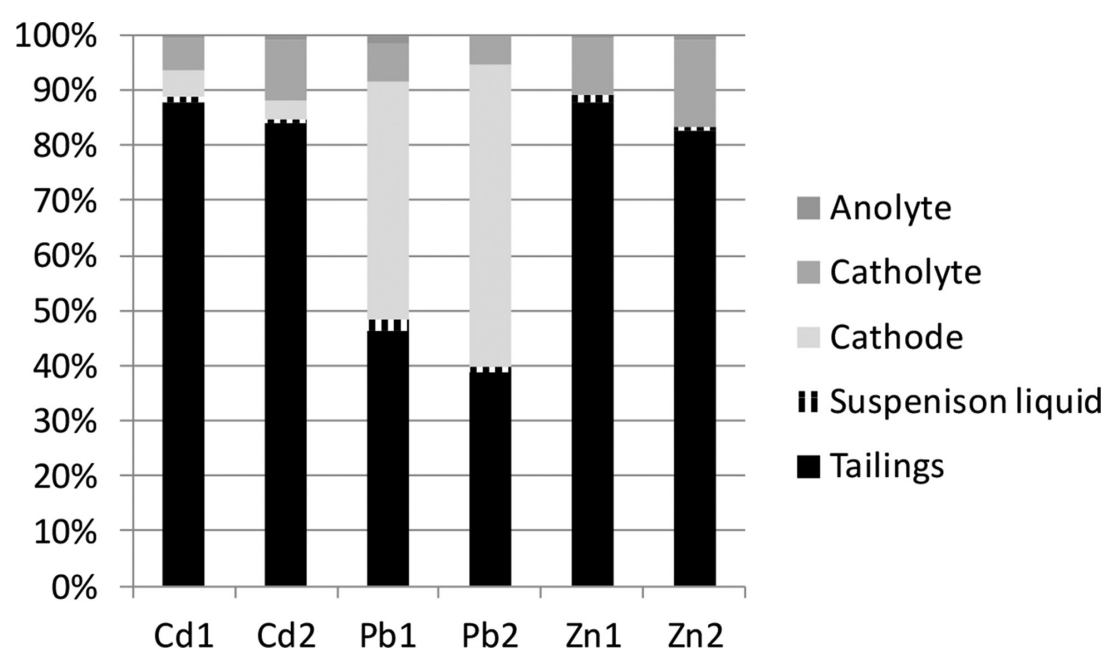

Figure 4: Results of $\mathrm{Cd}, \mathrm{Pb}$, and $\mathrm{Zn}$ removal from the two electrodialysis experiments ( 1 and 2) with Zinkgruvan tailings expressed as percent of the elements found in the various compartments of the ED cell. The amount in the electrolytes include small amounts $(<1 \%)$ found in the membrane material.

The voltage drop was between 2 and 3 volt in all experiments. At such low voltage drop and current density, energy consumption becomes minimal $(<80 \mathrm{kWh} /$ ton for the observed extraction). With no exemptions, the experiment show that the $\mathrm{Cu}$ removed from tailings is mainly precipitated at the cathode as metallic $\mathrm{Cu}$, and only small fractions are found in the liquid phases (electrolytes) (Fig. 3). This is the typical behavior for $\mathrm{Cu}$ [29]. 
Likewise typical was the behavior of $\mathrm{Pb}, \mathrm{Cd}$, and $\mathrm{Zn}$ extracted from Zinkgruvan tailings, as $\mathrm{Pb}$ was also mainly precipitated at the cathode, while $\mathrm{Cd}$ and $\mathrm{Zn}$ were mainly found dissolved in the catholyte liquid [29]. This behavior may be utilized to separate the elements. The $\mathrm{Pb}$ concentration was reduced significantly ( $>50 \%$ ), while $\mathrm{Cd}$ and $\mathrm{Zn}$ was reduced only slightly $(<20 \%)$. This is in contrast to what is normally observed when treating contaminated soils, in which $\mathrm{Zn}$ and $\mathrm{Cd}$ are most often found to be the most mobile elements [29], and showing that the specific mineralogical bonding of $\mathrm{Cd}$ and $\mathrm{Zn}$ in this tailing may significantly reduce their mobility.

\section{CONCLUSIONS}

EDR was shown to be a potent method for detoxification of tailings as it was generally possible to extract residual $\mathrm{Cu}$ from the three investigated tailings by electrodialysis in suspension independently of tailings origin at low-energy consumption. $\mathrm{Pb}$ could also be extracted from the Zinkgruvan sediment, while $\mathrm{Cd}$ and $\mathrm{Zn}$ are less mobile in these tailings. Both $\mathrm{Pb}$ and $\mathrm{Cu}$ precipitated at the cathode and can thus be recovered in their metallic form.

\section{REFERENCES}

[1] Kim, S.O. \& Kim, K.W., Monitoring of electrokinetic removal of heavy metals in tailing-soils using sequential extraction analysis. Journal of Hazardous Materials, 85, pp. 195-211, 2001. http://dx.doi.org/10.1016/S0304-3894(01)00211-4

[2] Kim, S.O., Kim, K.W. \& Stüben, D., Evaluation of electrokinetic removal of heavy metals from tailings soils. Journal of Environmental Engineering, 128, pp. 705-715, 2002. http://dx.doi.org/10.1061/(ASCE)0733-9372(2002)128:8(705)

[3] Baek, K., Kim, D.H., Park, S.W., Ryu, B.G., Bajargal, T. \& Yang, J.S., Electrolyte conditioning-enhanced electrokinetic remediation of arsenic-contaminated mine tailing. Journal of Hazardous Materials, 161, pp. 457-462, 2009.

[4] Isosaari, P. \& Sillanpää, M., Effects of oxalate and phosphate on electrokinetic removal of arsenic from mine tailings. Separation and Purification Technology, 86, pp. 26-34, 2012. http://dx.doi.org/10.1016/j.seppur.2011.10.016

[5] Hansen, H.K. \& Rojo, A., Testing pulsed electric fields in electroremediation of copper mine tailings. Electrochimica Acta, 52, pp. 3399-3405, 2007. http://dx.doi.org/10.1016/j.electacta.2006.07.064

[6] Hansen, H.K., Lamas, V., Gutierrez, C., Nuñez, P., Rojo, A., Cameselle, C. \& Ottosen, L.M., Electro-remediation of $\mathrm{Cu}$ mine tailings. Comparing $\mathrm{Cu}$ removal efficiencies for two tailings of different age. Minerals Engineering, 41, pp. 1-8, 2013. http://dx.doi.org/10.1016/j.mineng.2012.10.002

[7] Jensen, P.E., Ottosen, L.M., Hansen, H.K. \& Kirkelund, G.M., Suspended electrodialytic remediation for detoxification of copper-mine tailings. Proceedings of International Conference on Sustainability in Mining in the Arctic, ed. P.E. Jensen, Arctic Tecnology Center, Technical University of Denmark, pp. 81-86, 2013.

[8] Rojo, A., Hansen, H.K. \& Ottosen, L.M., Electrodialytic remediation of copper mine tailings; Comparing different operational conditions. Minerals Engineering, 19, pp. 500-504, 2006.

http://dx.doi.org/10.1016/j.mineng.2005.08.016 
[9] Hansen, H.K., Ribeiro, A.B., Mateus, E.P. \& Ottosen, L.M., Diagnostic analysis of electrodialysis in mine tailing materials. Electrochimica Acta, 52, pp. 3406-3411, 2007. http://dx.doi.org/10.1016/j.electacta.2006.05.066

[10] Hansen, H.K., Rojo, A. \& Ottosen, L.M., Electrokinetic remediation of copper mine tailings - Implementation of bipolar electrodes. Electrochimica Acta, 52, pp. 33553359, 2007. http://dx.doi.org/10.1016/j.electacta.2006.02.069

[11] Rojo, A., Hansen, H.K. \& Campo, J.D., Electrodialytic remediation of copper mine tailings with sinusoidal electric field. Journal of Applied Electrochemistry, 40, pp. 1095-1100, 2010. http://dx.doi.org/10.1007/s10800-010-0074-1

[12] Rojo, A., Hansen, H.K. \& Cubillos, M., Electrokinetic remediation using pulsed sinusoidal electric field. Electrochimica Acta, 86, pp. 124-129, 2012. http://dx.doi.org/10.1016/j.electacta.2012.04.070

[13] Lee, K.Y., Yoon, I.H., Lee, B.T., Kim, S.O. \& Kim, K.W., A novel combination of anaerobic bioleaching and electrokinetics for arsenic removal from mine tailing soil. Environmental Science and Technology, 43, pp. 9354-9360, 2009. http://dx.doi.org/10.1021/es901544x

[14] Ottosen, L.M., Jensen, P.E., Kirkelund, G.M., Ferrira, C.M.D. \& Hansen, H.K., Electrodialytic remediation of heavy metal polluted soil - treatment of water saturated or suspended soil. Chemical Engineering Transactions, 28, pp. 103-108, 2012.

[15] Hansen, H.K., Rojo, A., Pino, D., Ottosen, L.M. \& Ribeiro, A.B., Electrodialytic remediation of suspended mine tailings. Journal of Environmental Science and Health Part A, 43, pp. 832-836, 2008. http://dx.doi.org/10.1080/10934520801974020

[16] Windsor, C.R., Cavieres, P., Villaescusa, E. \& Pereira, J., Rock stress tensor measurements at El Teniente Mine, Chile. Proceedings of International Symposium on In-situ Rock Stress, eds, M. Lu, C.C. Li, H. Kjørholt \& H. Dahle, pp. 67-72, 2006. http://dx.doi.org/10.1201/9781439833650.ch9

[17] Rojo, A., Hansen, H.K. \& Guerra, P., Electrodialytic remediation of copper mine tailing pulps. Separation Science and Technology, 44, pp. 2234-2244, 2009. http://dx.doi.org/10.1080/01496390902979578

[18] Hedstroem, P., Simeonov, A. \& Malmstrom, L., The Zinkgruvan ore deposit, southcentral Sweden; a Proterozoic, proximal $\mathrm{Zn}-\mathrm{Pb}-\mathrm{Ag}$ deposit in distal volcanic facies. Economic Geology, 84(5), pp. 1235-1261, 2008. http://dx.doi.org/10.2113/gsecongeo.84.5.1235

[19] European Commission, Management of Tailings and Waste-Rock in Mining Activities. European Commission, Joint Research Centre, Institute for Prospective Technological Studies: Seville, Spain, p. 511, 2009.

[20] Lövgren, L., Hedlund, T., Malm, L. \& Karlsson, T., Immobilisation of trace metals in sulfidic mine tailings. Proceedings of the 11th International Mine Water Congress, Mine Water-Managing the Challenges, eds. T.R. Rüde, A. Freund \& C. Wolkersdorfer, IMWA, Aachen: Germany, pp. 387-392, 2011.

[21] Secher, K., Stendal, H. \& Stensgaard, B.M., The Nalunaq gold mine. Geology and Ore, 11, Geological Survey of Denmark and Greenland, 2008. 
[22] Steenfelt, A., Geochemical signatures of gold provinces in South Greenland. Transactions of the Institutions of Mining and Metallurgy, Applied Earth Science, 109, pp. B14-B22, 2000.

http://dx.doi.org/10.1179/aes.2000.109.1.14

[23] Stendal, H. \& Secher, K., Gold mineralisation and gold potential in South Greenland. Geology and Ore, 1, Geological Survey of Denmark and Greenland, pp. 2-12, 2002.

[24] Schlatter, D. \& Olsen, S.D., The Nalunaq gold mine: a reference sample collection and compilation and interpretation of geochemical data, 31, Geological Survey of Denmark and Greenland, 2011.

[25] Lewis, A., New Inco tech process attacks toxic cyanides. Engineering and Mining Journal, 185(7), pp. 52-54, 1984.

[26] Dansk Standardiseringsraad., DS259:2003. Determination of metals in water, sludge and sediments - General guidelines for determination by atomic absorption spectrophotometry in flame, 2003.

[27] Mielke, J.E., Composition of the Earth's crust and distribution of the elements. Review of Research on Modern Problems in Geochemistry, ed. F.R. Siegel, pp. 13-37, 1979.

[28] Nystroem, G.M., Ottosen, L.M. \& Villumsen, A., Acidification of harbour sediment and removal of heavy metals induced by water splitting in electrodialytic remediation. Separation Science and Technology, 40, pp. 2245-2264, 2005. http://dx.doi.org/10.1080/01496390500201367

[29] Jensen, P.E., Ottosen, L.M. \& Allard, B., Electrodialytic versus acid extraction of heavy metals from soil washing residue. Electrochimica Acta, 86, pp. 115-123, 2012. http://dx.doi.org/10.1016/j.electacta.2012.07.002 